\title{
Communication for Social Change in Indigenous Communities; Limitations of Community Radios and Other Proposals
}

\author{
Igloolik Isuma Productions
}

Bianca Rutherford Iglesias and Concepción Travesedo de Castilla

The radio is the most used means of communication in social change projects in indigenous communities. However, it is not free from problems regarding invisibility, isolation and inbred knowledge. Communities who depend exclusively on this media seldom broadcast their messages outside their environment. They are doomed to a paradoxical isolation within a new international society where most local needs have global causes and solutions. Moreover, its inbred nature makes it difficult for the construction of knowledge networks, which can enrich a culture with foreign elements. That is the reason why it is timely to study the possibilities offered by new technologies to adopt strategies in the field of communication for social change. In this paper we are analyzing the sample from the Inuit film company Igloolik Isuma Productions. It is our intention to describe the strategy used by this private, independent company to become an economic, social and political force of change within its indigenous community since 1990. This objective has been partially achieved thanks to Isuma TV online, which links and offers services and contents to indigenous producers all over the world. To sum up, Igloolik Isuma is a great example of success for experts in communication for social change who are reticent to accept the tremendous possibilities offered by new technologies and hybrid projects based on Internet usage.

\section{The Starting Point: the Self-Management of Social Media}

The relationship between communication and human development has been discussed by Everett Rogers, ${ }^{1}$ Wilbur Schramm $^{2}$ and Daniel

1 Everett M. Rogers, ed., Communication and development: Critical perspectives. (Beverly Hills, CA: Sage, 1976).

2 Wilbur Schramm, Mass media and national development. (Stanford, CA: Stanford University Press, 1964).

(C) IGLESIAS AND DE CASTILLA, 2015 | DOI 10.1163/9789004282087_016

This is an open access chapter distributed under the terms of the prevailing CC-BY-NC License

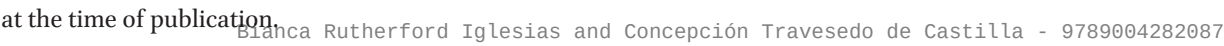


Lerner, ${ }^{3}$ the promoters of the first academic studies on this topic. Thereafter it is assumed that social media play a major role in spreading new possibilities and practices within the processes of cultural innovation and development, to encourage greater participation of citizens in society, and to help them acquire the skills that progress demands. ${ }^{4}$ The current perspective of development communication goes further by rejecting the one-way vertical communication broadcasting models and assuming that the development is accelerated by active participation of each individual in the communication process itself. People should be informed in order to solve their problems, and that information is provided by the media. Furthermore, if the media are accessible, the community can make its information needs known and discuss their actual living conditions.

In this regard, the most developed form of participation should be the selfmanagement principle which implies the right to participate in the planning and production of media content. The essential elements of a participatory communication project should be the following: ownership of the project by the community to achieve self-management, a minimum of experience and knowledge of the field, and the creation of horizontal communication networks capable of channeling the messages to outsiders and reach an audience to share knowledge and experiences.

According to Gumucio-Dagron, "the most successful strategies of development communication are those that fortify their own traditional means of communication, amplifying the local speeches and anchoring them in culture. ${ }^{5}$ The majority of theorists adhere to this premise. Moreover, they argue that mass media and traditional ways of transmitting oral communication should include mechanisms of horizontal, dialogical and participatory communication. These communication paths should be combined in different ethnic environments. Besides, Jaen Servaes is in favor of the integration of diverse media "The modern mass media and the parallel networks of folklore or interpersonal media are not defined as mutually excluding. In certain contexts, both can achieve longer-range success if used in an integrated manner considering the needs and peculiarities of the local context."6

3 Wilbur Schramm and Daniel Lerner, Communication and change: The last ten years and the next. (Honolulu, HI: University of Hawaii Press, 1976).

4 Luis Ramiro Beltrán Salmón, "La comunicación para el desarrollo en Latinoamérica: un recuento de medio siglo" (Paper presented at III Congreso Panamericano de la comunicación, Universidad de Buenos Aires, July 12-16, 2005).

5 Alfonso Gumucio-Dagron, “¿Prometeo viajando en Cadillac?: los telecentros como el prometido fuego del conocimiento," in Signo y Pensamiento 44 (2004b), 84-91.

6 Jean Servaes, “Comunicación para el desarrollo. Tres paradigmas, dos modelos," in Temas y Problemas de Comunicación 10 (2000), 25. 
However, it has to be emphasized that the commitment to outlining a dialogue between new media and traditional channels of oral transmission, which is particularly relevant to the development of certain minority ethnic groups, makes sense only if accompanied by horizontal and participatory management. It is only in this context that we can, according to UNESCO, accomplish "the most advanced and comprehensive form of participation": self-management. ${ }^{7}$ In this regard, the strategy should contribute to a media ownership by the community and its autonomy from external players, as well as the ability to use these tools according to their particular way of understanding life. It is basically a question of making media available to the needs of the community, responding to their demands and thus contributing to the preservation and strengthening of their cultural identities.

The aim is, thus, to address an analysis of the capacity of modern media to, as Wilbur Schramm said, supply and complement as mobility multipliers or progress stimulus the oral channels of traditional societies. ${ }^{8}$ The purpose is to boost the community's progress from the best possible platform, that is, a reaffirmation of indigenous identity and integration without acculturation in a diverse environment.

Audiovisual production, the Internet, and other mixed resources give an example of successful strategies for social change in the new global and digital society. Although it is true that the most relevant models have emerged in developed contexts - both economically and in the field of individual rights and freedoms protection - the possibility of exporting and adjusting them to less privileged areas can be considered. Therefore, any study of the different examples of indigenous media that can be found around the world leads us to the conclusion that each community should choose the kind of medium that best suits their needs. However, this entails being aware of every alternative and being open to the possibility of incorporating more sophisticated technologies than the radio. Communities should appropriate the media and redesign them according to their particular cultural interests. They should not assume that ICTs are only useful when utilized the same way dominant cultures have been traditionally using them. ${ }^{9}$

In this paper we intend to comprehensively analyze the possibilities offered by a medium such as audiovisual production, which helps visibility and asserts

7 Luis Ramiro Beltrán Salmón, "Un adiós a Aristóteles: La comunicación 'horizontal," in Comunicación y Sociedad 6 (1981), 5-35.

8 Jean Servaes, "Comunicación para el desarrollo. Tres paradigmas, dos modelos," in Temas y Problemas de Comunicación 10 (2000), 19.

9 Faye Ginsburg, "Rethinking the digital age," in Global indigenous media: cultures, poetics, and politics, ed. Pamela Wilson et al. (Durham: Duke University Press, 2008), 289-29o. 
identities. We are also investigating the ability of the World Wide Web, that is, integration and construction of knowledge networks, to assert human development projects based on the creation of self-managed media. We are choosing the Inuit film production company Igloolik Isuma Productions to investigate the many possibilities offered by this model.

\section{The Limitations of Community Radio: Invisibility, Isolation and Inbred Knowledge}

It has been a long time since community radio started to be considered the most advantageous media to foster the progress of indigenous communities. Undoubtedly, radio is the most widely used media for this purpose, and it is considered to be of utmost importance by most researchers. The five fundamental characteristics of community radio stations are accessibility, participation, self-management, ownership and responsibility; ${ }^{10}$ in other words, its tendency to meet the needs of the community, to pursue the participation of community members in the ownership, production and transmission of message, and its conception as a nonprofit public service.

Generally speaking, these educative, popular or community media boost agricultural development, political participation, access to healthcare information, social transformation, identification of common interests, cultural protection, etc. According to Gumucio-Dagron, "radio has been the most appealing instrument for communication and participatory development for more than fifty years. It is certainly the most widespread communication tool in the world and the ideal means to accomplish social change."11 Its simplicity and low cost, as well as the ability to reach the most isolated and excluded communities, overcoming geographical distance and illiteracy, turn radio into the pioneer and model media in the field of participatory communication.

Despite the success achieved with community radio, some possible collateral effects should be identified in the spheres of invisibility, isolation, and inbred knowledge. Communities who found their development strategies in the use of community radio stations have little capacity to channel their

\footnotetext{
10 Louie Tabing, How to do community radio. A primer for community radio operators (Nueva Delhi: UNESCO, 2004), 11-12.

11 Alfonso Gumucio-Dagron, ed., Haciendo olas. Estudio de comunicación participativa para el cambio social. (Nueva York: The Rockefeller Foundation, 2001), 15.
} 
messages abroad; they do not opt for visibility, and when they do, they do not focus on integrating in diverse environments. In many occasions they preserve an isolation that seems paradoxical in the new global society, where all local needs have, at least partially, a global root and solution. Finally, its inbreeding nature makes it difficult to build networks of knowledge that could enrich typical cultures and traditions with elements of knowledge and cooperation from abroad.

Community radios are helping to preserve languages and traditions in small settlements, but they do not spread their cultural wealth beyond the own ethnic group boundaries. In the new global society, where social interaction can either develop into conflict or cooperation, integration within diversity seems to be an unavoidable challenge. Therefore, one of the highest restrainer features of community radio can be situated in the area of visibility. The pro indigenous spirit that commonly assembles these community media preserves in many cases the invisibility of the group. The strictly native communal media, those who place ownership and management exclusively in the hands of the community, are frequently week potency radios unable to surpass the confines of the regional area in which they operate. ${ }^{12}$

As Carlos del Valle says, many researches have been conducted on indigenous communities and media, but they have been mostly focused on the representations of ethnic groups in media discourse, being the purpose of analysis centered on the media rather than on the ethnic groups. That is to say, the discourse on minorities is only an excuse to study media behavior.

But, who are we talking about in this comprehensive exercise? We think we understand other communities in these analysis, but what we really do is a self-reference, and in this continuous self-reference we cause two effects: (a) an inevitable distortion of the other- although we understand that it is not possible to avoid this deformation, and (b) a discourse centered in a self-reference (...), in which symbolic elements are selected by observers, in an exercise of invention of what is observed. ${ }^{13}$

At this point, the crucial task for indigenous and minority communities is to take up the challenge of boosting their visibility not by intermediation, but by

12 Maurizio Alí, "Medios de comunicación, asuntos étnicos e intercultura en Colombia," in Razón y Palabra 74 (2010), 6.

13 Carlos del Valle, "Mediacentrismo e invisibilización de lo étnico como objeto de estudio: una genealogía crítica de la comunicación intercultural," in Signo y Pensamiento 46 (2005), 51-64. 
their own appropriation of media, especially media capable of reaching a global audience.

In addition to the limitations of community radio in the decisive sphere of visibility, the "communal" nature of these media also implies a tendency towards isolation from the environment in which, in a more or less conflicting way, they are immersed. And this is a problem in a context where the main decision-making centers go beyond boundaries and overcome national borders. This demonstrates the loss of power not only in the local environment, but also at national levels.

The complexity of international society implies that nations have increasingly constricted room to respond to the interests of citizens. National states confront problems of global size and nature that seriously destabilize their internal structures. Among these problems, poverty stands out, a way of life with common features in every local process of reproduction in all states, albeit with local variations. Consequently, socio-cultural transformations are required to accommodate translocal solutions and new development strategies, that is, different organizational structures which are able to cover the diverse transversal dimensions of poverty, ready to promote social integration, popular action and participation. All these purposes demand focusing on new instances of social action that could well be supranational organizations coordinated with social movements and NGOS, or cross-border regions organized and synchronized with national states. ${ }^{14}$

Finally, returning to the limitations of community radio, we believe that it is not worth to ignore the technological tsunami that is revolutionizing the global communications field, social participation, and certain processes of democratization in developing countries. All in all, communities cannot be condemned by technophobic prejudice to exclude a few communication flows that are developed by radically different parameters. In fact, among the most suggestive features of the most technologically advanced media we can find their capacity to promote the construction of Knowledge-Based Networking. According to Vikas Nath,

Knowledge Based Networking rests on the strong belief that communities have knowledge and expertise which needs to be synergized with the existing information [...] Just as the knowledge gap needs to be bridged between developing and industrial countries, so there are gaps within the

14 Sybil Lorena Caballero, "Prácticas emergentes: la ciberdemocracia, las telecomunidades de conocimiento y los telecentros como alternativa para el desarrollo," in Cuadernos del cendes $5^{8}$ (2005), 97-116. 
country. Knowledge Based Networking bridges the gap between the communities [...] it allows access to information worldwide, promotes networking transcending borders, languages and cultures, fosters empowerment of communities and helps spread knowledge about best practices and experiences. It implies that knowledge is acquired not just by creation but also by transfer of knowledge existing elsewhere. [...] Networking for knowledge-sharing caters to the global thirst for information, builds up awareness among the change agents or those who can exert external pressure, and encourages informed and active participation of communities and individuals. Furthermore, it creates a mechanism which enables articulation and sharing of local knowledge with potential for further enrichment of this information as it passes through the network users. ${ }^{15}$

At this point, it is worth recalling the Declaration of Principles of the World Summit on Information Society (wsis) where the importance of the new context and its possible impact on solving common problems has been emphasized. The new way of how to create and share knowledge can yield benefits and positive transformations to our society. ${ }^{16}$

According to Stephen Browne, we are talking about a new paradigm that defines the most important means of acquiring knowledge; those that arise from a combination of local knowledge with the knowledge we acquire from elsewhere. It indicates a rejection of the traditional model that considers that the leading economic powers will always be "the opposing expert" and acceptance that the information can or cannot be useful whether it is from the South or from the North. The concept represents the process of cultural interaction from an intercultural viewpoint that sees globalization as the compression of cultures, far from the nuanced theories that argued that the globalization of communication and culture promotes imperialism and cultural homogenization. ${ }^{17}$

15 Vikas Nath, "Knowledge networking for sustainable development," KnowNet Initiative (200o): <http://216.197.119.113/vikas/exchanges-ict.html>, visited August 152013.

16 Cumbre Mundial sobre la Sociedad de la Información, Declaración de principios. Construir la Sociedad de la Información: un desafío global para el nuevo milenio, Documento WSIS03/GENEVA/4-S. ONU-UIT (2004): <http://www.itu.int/wsis/docs/geneva/official/dop-es .html $>$, visited on 15 August 2013 .

17 Jean Servaes, "Los medios de comunicación: globalización a través de la localización," Revista Científica Digital 3 (2001): <http://www2.metodista.br/unesco/PCLA/revista7/ artigo\%207-3.htm\#Principaislinks>, visited on 15 August 2013. 
In conclusion, if the creation training is and ought to be an indigenous phenomenon with idiosyncratic features following the endogenous process focused on local context, "the development of capacity can also be accelerated and increased in response to external stimuli."18 ICTs should not be considered as an objective, but as a tool that can successfully participate in certain cases in communication projects for social change. As pointed out by Manuel Acevedo, the Network Society is here to stay, and it is not worth analyzing whether it is the best context to promote human development. The convenient step is to begin to study how we can maximize the best features and minimize obstacles in this new scenario. ${ }^{19}$

Applying this new approach to the traditional metaphor for development cooperation, it has been assumed that the strategy of giving a fish to a human being to end hunger is counterproductive in the long term. Furthermore, we know there is a better possibility than teaching them how to fish; that is to learn the traditional technique as a counterpart, to check if we know how to make nodes from the most solid networks and unite knowledge. On account of the possibilities of building knowledge and ICT network, it is also possible to build an information carrier to collect data on fish prices in different markets, weather and fishing conditions, species available, tips of other fishermen, spare parts stores, etc. ${ }^{20}$ In this context, it is worth pausing to examine the possibilities of integration of other media, such as video, films and the Internet to promote social change, preserve, enrich and spread the cultural identity and contribute to the development of minority social groups.

However, in the midst of the technological and communications revolution, radio remains to be the paradigmatic example of community media in large parts of Latin American and African societies in full communicative and technological revolution. In fact, given the scant attention to initiatives that exploit the synergies between new technologies and traditional media, such as film or radio, and also meet the requirements to be considered successful participatory communication projects, we find vast literature on the community radio.

18 Stephen Browne, "Introduction: rethinking capacity development for today's challenges," in Developing capacity through technical cooperation, ed. Stephen Browne (Virginia: Earthscan Publications, 2002): iv-vi.

19 Manuel Acevedo Ruiz, "Información, conocimiento y Tics: la cooperación al desarrollo en la sociedad red," (paper presented at Aula Solidaridad, Comillas, Universidad Pontificia de Comillas, April 20, 2006).

20 Manuel Acevedo Ruiz, "Los desafíos para la integración de las TIC en una cooperación en red" (paper presented at Cooperación 2.0, I Encuentro Internacional sobre Tics para el Desarrollo. Gijón, FIDMA, January 30-31, 2008). 
This extensive bibliography stripe is so repetitive, that it often leaves the impression of being an exhausted field of study which has not had either epistemological or real practical progress in a long time.

As long as this inexpensive technology allows an indisputable success in a context of economic marginalization and / or policy, there are other scenarios with similar or different issues in which it is possible and advisable to use different communication tools. The purpose is not only domestic integration and development of the community, but also its visibility and acceptance in an environment culturally and ethnically different. The best experience of communication for development is found in economically prosperous contexts with legislation in the field of equal opportunities and human rights so far. Although it is not an unconditional requirement, areas with better conditions are turning to more advanced technologies, as in the case of indigenous Inuit (Canada), Sami (northern Europe), Maori (New Zealand) and other American Indian communities in the United States.

These examples, highlighting the successful Inuit film producer Igloolik Isuma Productions, may serve as models for the expansion of development strategies based on the use of audiovisual production and/or the Internet to other economically disadvantaged settings. On account of previous experience, the new technologies can also get results and even response to needs that community radio cannot meet in less economically prosperous systems.

\section{The Possibilities of Videos and Films in the Field of Communication for Social Change}

Although Latin America is not the region where the most successful videobased projects of social change communication have been developed, we find some examples applied to the field of rural development as early as the 1970s. Calvelo Manuel Rios is found among the pioneers, as a FAO expert and creator of Massive Training Methodology Studies, later known as Massive Multimedia Pedagogy. ${ }^{21}$ The MMP, which challenges the theoretical model of informationtransmitter-receiver model, takes as its motto the following Confucius quote, "I hear and I forget. I see and I remember. I do and I understand."

However, the audiovisual production reached its peak as a means of social development in the '80s, when the documentary or ethnographic film broke the classical paradigm according to which "we" were always filming "them."

21 Manuel Calvelo Ríos, "La pedagogía masiva multimedial," in Revista Latinoamericana de Estudios Educativos 4 (1998), 197-205. 
From the moment that indigenous peoples managed and appropriated audiovisual production, they also became primarily responsible for creating their own image. At first some artists preferred to work with settled directors as the activist Vincent Carelli at the Indian Trabalho Center of Sao Paulo, and Sarah Elder and Leonard Kamerling at the Alaska Native Heritage Project. Others collaborated with anthropologists such as Terry Turner, who started the Kayapo Video Project. The rest was introduced to film production individually, like the video artist and activist Victor Masayesva Hopi, Jr, and producer and director Zacharias Kunuk Inuit. ${ }^{22}$

The global media has become a powerful field of audiovisual productions. Giving as an example the milestone movie Pathfinder (1987) directed by Nils Gaup Sami and seeing the more recent Smoke Signals (1998) and Atanarjuat: The Fast Runner (2001), it is obvious that directors and indigenous activists have appropriated the technologies used by the leading economic powers to document cultural traditions, counteract distortions of Aboriginal peoples, and build indigenous cultural future. The awards reaped by many of the productions in international film festivals and streams of sympathy for indigenous issues planted in international public opinion demonstrate the importance of production. Moreover, the relevance of documentaries implies having the ability to become known abroad. And last, but not least, the media are playing a crucial social role by providing a tool for the creation of new practices of solidarity, identity and community.

Since the birth of such productions, a broad range of researchers have analyzed how the communication technologies are being transformed and adapted to meet the needs of indigenous communities. The research was conducted following objectives such as the creation of screen memories, their importance in activism in the Amazon and Brazil and other indigenous communication initiatives in Latin America, the impact of Inuit film and ways of representation of identity in the video Amerindian. Likewise, the investigation focused on the efforts to "colonize" the screens, that is, the different national cultural policies that either promote or constrain native media production, or native esthetical representations in indigenous media.

The festival First Nation / First Features: a showcase of World Indigenous Film and Media, screening a vast repertoire of films created by indigenous directors from around the world, was held in New York in 2005. The films echoed how to resort the narrative traditions in order to create cinematographic visions that highlight the old indigenous cultural worlds, integrating

22 Faye Ginsburg, "The parallax effect: the impact of aboriginal media on ethnographic film," in Visual Anthropology Review 2 (1995), 64-76. 
them into contemporary narrative models with the ability to access local and global audiences. It also demonstrated the way this can be achieved by covering a huge variety of styles and content, the most common remains to be family relationships, the transfer of traditional legends to the screen, the contemporary reality and the difficulties of integration into urban lifestyles in these communities, and its links to Earth. ${ }^{23}$

Essentially, all the indigenous media have a political component that, at least, calls for the preservation of their own language and culture. Similarly, these media have not escaped the thorny and controversial issues affecting their own indigenous movements. There have been attempts to cross certain boundaries and reach other aboriginal communities that have served as a platform to claim the possession of land and have demanded competence to be creators of their own image.

Beyond its artistic value, indigenous film production attracts community organization and has become a tool of social and cultural appropriation. The cheaper technology, especially in the case of video, has helped democratize audiovisual production. Therefore, the ability to create movies, series and documentaries does no longer belong exclusively to major film and television companies, but form a part of community life. The community video production can contribute to personal and collective empowerment and to the demystification of commercial media; it can reverse the roles of power and fortify collective strength.

The media can contribute to cultural resistance, as reflected by hundreds of indigenous professionals who work daily on the radio and to a smaller extent, on television. The resistance can be consolidated by the indigenous cinema and it helps cultural and linguistic normalization. Moreover, it can afford to do so with a subversive formula by resorting to fiction. The anthropological report and political pamphlet can be avoided by the narration. In fact, the most subversive of indigenous films can be apolitical in appearance. The love stories and thrillers can symbolize more effective forms of resistance than activists' productions. Even when using a minority language in a non-political way, it is located at the same level as the dominant language. Consequently, a film which does not appear to be political turns to be even more political, precisely because it does not seem to be so. Thus, this type of films can be considered a strategy of cultural resistance among other reasons because it breaks

23 Kristin Dowell, "Indigenous media gone global: strengthening indigenous identity on- and off-screen at the First Nations/First Features film showcase," in American Anthropologist 2 (2006), 376-384. 
stereotypes, it is expressed in the minority language and uses fiction in a subversive way. ${ }^{24}$

\section{The Internet as a Source of Opportunity, Stand-Alone or Integrated Hybrid Project}

The acceptance of video and films as a tool for social development projects for their "creativity and ability to adapt to the flux of social and cultural contexts" 25 contrasts with the arousing suspicion of the Internet. It was defined by Gumucio-Dagron and many other authors as the main responsibility of the electronic apartheid: "The availability of computers and connectivity is not a cure for development and social change because the network, as configured, is not an ideal tool for the majority of the world's population." ${ }^{26}$ On the other hand, we agree more with the thesis defended by scholars like Manuel Acevedo and activists such as Jean-Paul Marthoz. From Ruiz's perspective, it would be just a false myth that information technology and communication increase inequality or inequity.

While at an early stage of development the technologies tended to amplify the differences, their future depends on the prevailing economic and social models. There are examples of cases when national policies were committed to extend the benefits of ICT to the whole society (Korea, Ireland, Latvia, Jordan, and Venezuela). Despite the fact that the global digital division is extensive, it will be restricted as has happened to other ICTs (radio, TV, telephone). The following reflection by Acevedo is difficult to refute: "Do public libraries contribute to increase the inequality between the more favored literate and illiterate people? Would it be a reason to prevent its construction or close them until the universal literacy will be accomplished?"27

Meanwhile, Marthoz emphasized that new technologies of information and communication have enhanced capabilities of civic organizations "Thanks to

24 Antoni Castells i Talens, "Cine indígena y resistencia cultural," in Chasqui 84 (2003), 50-57.

25 Alfonso Gumucio-Dagron. "Televisión comunitaria: ni pulpo, ni púlpito, Pálpito," Infoamerica (2006): <http://www.infoamerica.org/articulos/textospropios/gumuciozb .htm>, visited May 202010.

26 Alfonso Gumucio-Dagron, "El cuarto mosquetero: la comunicación para el cambio social," in Investigación y Desarrollo 12 (2004a), 2-23.

27 Acevedo, "Información, conocimiento y тісs." 
modern media, especially the Internet, the global networks can create, mobilize, and act easily." 28 The motto do not hate the media, be the media that was proclaimed by the supporters of alternative information is not only valid for industrialized countries. Even in Côte d'Ivoire there are hundreds of African Internet users who got connected immediately to the website of Human Rights Watch to get the report in which abuses of their government were exposed.

However, certain technophobia or at least skepticism is still generally perceived, regarding the ability of the Internet to become a useful and adaptable source for disadvantaged minorities. This is likely to happen because many of the leading theorists and experts on social change communication fields come from Latin America, where, in general, the communication is still committed mostly by community radio. Gumucio-Dagron in his famous 2001 work "Making Waves. Stories of Participatory Communication for Social Change" does recognize the potential benefits of hybrid projects that combine video and the Internet. The study was a result of an initiative of the Rockefeller Foundation, which promoted a series of meetings of experts in order to reflect on communication for social change at the dawn of the new millennium from April 1997 to 2001. It reflects 50 experiences defined by the communications director of the Foundation, Denise A. Gray-Felder, as "some of the most innovative experiments in participatory communication in the world."29

The Bolivian academic assumed that "Although the video as a tool of participatory communication for social change is only in its very beginning [said in 2001], its potential is enormous, particularly because of expected convergence with Internet programs of high visual content. This convergence of wireless technology... with the radio and television" would be "the way forward," so that technology can form an appropriate response, while culture, identity and community participation should occupy the center of the discussion. ${ }^{30}$ Anyway, this monograph on the developments in the field of participatory communication for social change continues to take a chance on community radio as the best tool so that communities from the South could change the circumstances of their poverty, discrimination and exclusion.

Moreover, the study has a unique focus on countries in the South, particularly on regions of Latin America, Africa and Asia. The experience developed in indigenous communities integrated in the North is excluded. The Fourth World

28 Jean Paul Marthoz, "Comunicarse en un mundo globalizado," in Globalización, crisis ambiental y educación, ed. José Ignacio Flor et al. (España: Ministerio de Educación, 2002), 141-154.

29 Gumucio-Dagron, "Haciendo olas," 1.

3o Gumucio-Dagron, "Haciendo olas," 26-35. 
is characterized by exclusion or marginalization in the context of wealth and development such as the Inuit community in Canada, the Native Americans or Australian aborigines, despite the fact that we find exciting projects in between. The projects are designed to preserve and keep alive specific minority cultures threatened by the obligation to live and interact with companies that are real worldwide cultural powers. It is interesting to notice that major international agencies and institutions involved in the fight against the causes of poverty have been directing their gaze towards the many possibilities offered by ICTs and are behind the most important publications on the subject.

There has been an interesting research on the opportunities offered by the Internet together with radio broadcasting, but there is hardly any literature on other types of hybrid projects. However, the most ambitious works we have found about the relationship between ICTs and human development come from areas of study such as engineering telecommunications, education and even anthropology, while researchers in the field of mass communication appear to follow largely anchored technophobia when it comes to relating to media and social change.

Currently one of the main focuses of research on the potential of ICT for human development is the one at the Massachusetts Institute of Technology. The research seeks through various projects to dismantle myths such as the phone offering a better and cheaper opportunity to connect the isolated rural inhabitants than the Internet and digital messaging services. Examples like DakNet in India, Motoman Project in Cambodia and the organization First Miles Solutions, show the strength of the Internet usage based on the intermittent connection, asynchronous communication, which allows remote villages benefit from communication with the rest of the world which is 20 times cheaper than that of a telephone line. ${ }^{31}$

Although indigenous peoples are barely represented in cyberspace, information highways provide a platform for any community, no matter how isolated they are. All communities can increase the sphere of influence and gather political support in their struggle for cultural survival. In clear advantage to those who only rely on the radio, the communities that are already using the network and strengthening internal links are connecting with other indigenous peoples scattered throughout the world and creating networks for activism based on their many common interests. Of course, the use of the Internet and a new digital platform does not have to be the same as those used in the

$31 \quad$ Alex (Sandy) Pentland, Richard Fletcher and Amir Hasson, "DakNet: rethinking connectivity in developing nations," Journal Computer 37 (2004): 78-83, accessed August 15, 2013, doi: 10.1109/MC.2004.1260729. 
North. The application to be given will depend on their particular needs, encouragement of the development of networks of political activism, and the ability to make known their traditional cultures in other territories.

Several recent initiatives have helped us to envision the number of possibilities that are offered by hybrid projects, in this case in disadvantaged communities integrated in rich democratic countries. Igloolik Isuma, the independent film production company run by Inuits, mentioned in previous lines, has been distributing its work of filmmaking on its online portal for years, and offers coverage, live broadcasts and access to audiovisual archive collecting antique Inuit culture and tradition. As the creator of the site explains, "Isuma has coveted for a long, long time to use the Internet to connect to the remote Arctic peoples around the world, a way to bring people to Igloolik avoiding the enormous costs and difficulties involved scroll and allowing the Inuit to remain in their communities or away on the tundra without losing contact with the twenty first century." ${ }^{2}$ Us Mob, a project by Arrernte Aboriginal Australians living in the reserves of Alice Springs, is another example of youth online portal that broadcasts series and offers all kinds of interactive content to present the everyday life of children in the reserve. To quote its creator, David Vadiveloo, "I have tried to build a bridge of dynamic communication that Arrernte youth initiated in Alice Springs with an invitation to all children in the world to play, share and engage with stories that are common to all young people." ${ }^{33}$ To end with, the teen Canadian series The Raven's Tales, made by indigenous artists and writers using digital animation techniques, is another example of what anthropologist Faye Ginsburg defined as cultural activism. They use the media not only to preserve and build their communities, but also as a way to stimulate their transformation through what we might call strategic traditionalism. ${ }^{34}$ In addition to these cases, we will study in detail the successful example of Igloolik Isuma Productions.

\section{Conclusions: The Igloolik Isuma Productions Model}

The Inuit people, like all indigenous people, are heirs and bearers of a valuable cultural heritage, including their own perspective of the world. Despite having suffered from colonization, being evicted from their land and having their ethnic, linguistic and cultural identity suffocated, this community has shown

\footnotetext{
32 Ginsburg, "Rethinking the digital age," 296.

33 Ginsburg, "Rethinking the digital age," 297.

34 Ginsburg, "Rethinking the digital age," 302.
} 
great vitality and capacity to adapt. As Denis Lachate expresses it, "La flexibilité de leur système socio-culturel traditionnel pourrait bien se révéler finalement leur atout principal dans la création d'un nouveau mode de vie."35

Insofar as the world wide globalization processes introduce more and more challenges for indigenous peoples, there is a growing tendency to recognize that preserving these cultural heritages is necessary. This is because indigenous peoples who base their life styles in a flowing relationship with nature represent a model of sustainability and a sample to follow for the industrialized world.

Unfortunately, subsistence economy and a sustainable life style led by most indigenous peoples have not been enough to prevent the climate change impact, particularly in Arctic regions, which are the most affected according to many scientists. Climate change impact in this area is so high that the traditional Inuit lifestyle is being questioned. It is a lifestyle that has ice and snow as the basis of their culture. Having said that, we have to realize that this is a community whose culture, based on oral transmission, is having to face an inter-generational breach in their transmission process. This fact shows the urgency to find solutions that allow the preservation of their cultural heritage. A good example of this search for a solution to preserve and broadcast the Inuit intangible heritage is the first independent Inuit production company Igloolik Isuma Productions. Their objective is to retake their culture through the production of fiction films and documentaries from their own perspective and language.

Igloolik Isuma Productions was created in 1990, at Igloolik, Nunavut to produce films and broadcast the Inuit culture and symbolic language. Seventy five per cent belongs to the Inuit community and all of its founders, except Norman Cohn, who is co-founder and treasurer, are Inuit. From its inception, Isuma was known for its original style, breaking barriers between documentaries and fiction, staging a new way to understand the world. Among its most representative productions we have docudramas that seek to create the Inuit lifestyle. The most significant production is the series Nunavut, or Our Land. However, its most remarkable production may be the film Atanarjuat, the Fast Runner, based on a traditional Inuit legend. The film won the Caméra d'or award at the Cannes festival, 2001. Atanarjuat has also been the first Canadian film in Inuktitut language and all its actors are Inuit inhabitants within the community. This film tries to transmit as faithfully and truthfully as possible an

35 Denis Lachance, "Les inuit du Québec," in Perspectives anthropologiques. Un collectif d'anthropologues québécois, ed. Louis Jaques Dorais (Montréal: Les Éditions du Renouveau pédagogique, 1979), 289-303. 
important legend in the Inuit tradition that would be very difficult to reproduce outside fiction, in order to respect the Inuit ancestral vision, including shamanism, mixing the real world, legends and dreams.

Fom January 2008, the production company also has an online support, that is, Isuma TV. This is a multimedia platform whose main objective is to link different indigenous directors all over the world so that they can post and share their audiovisual productions. The videos sent can be visualized through the web free of charge. At the moment, the web is offering more than 1000 indigenous video productions in thirty different languages. From April 2009, new services were added and Isuma TV became Isuma TV 2.o. After the latest update, the site allows, among others, the following services:

- Upload and exchange multimedia content with people and communities anywhere in the world.

- Create a cannel, group or blog.

- Invite users to become cannel members and keep them informed of updates and activities.

- Import other blogs to Isuma TV.

- Watch videos and make comments through writing, audio or video.

In its site, Isuma offers live coverage and broadcast plus access to an audiovisual archive made of old items that reflect the Inuit tradition and culture. As the designer of the site explains, "For a long time, Isuma has longed to use internet to connect the far Arctic with peoples all over the world, in an attempt to bring individuals to Igloolik without the enormous cost of travelling here, as well as to make it possible for the Inuits to stay in their communities or deep in the Tundra in touch with the twenty first century." 36

Simultaneously to audiovisual and multimedia productions, Isuma takes active part in the development and empowerment of Igloolik and Nunavut communities, enhancing employment and organizing activities aimed to different sectors or this community. These are among them:

- Tarriasuk Video Centre, the first non-profit film school in the Arctic, founded by Isuma in 1991 with the help of Canada Council of the Arts.

- Arnait Video Productions, the first independent production company made by Arctic women. From its creations in 1999, it produces audiovisual programs and contents form the Inuit woman point of view. This group assisted Isuma with the script and direction of the film Before Tomorrow (2007).

36 Ginsburg, "Rethinking the digital age," 300. 
- Innusiq, or Life, is a drama group for youngsters created in 1999. With the aim of fighting suicide among the young people in Nunavut, that has alarming suicide rates, through artistic activities.

- Artcirq, the same as Innusiq, has made its main objective to raise awareness among the Inuit youth about the meaninglessness of suicide as a way to end their problems. Born in 1998, this is a social circus that combines current doctrines with traditional Inuit based techniques.

Regarding Isuma's filmography, they have twelve documentaries, three fiction films and two TV series, as well as some films of its own and some experimental co-produced films. These include the already mentioned Atanarjuat, the Fast Runner, awarded in Cannes. The fact that a film such as this one has gone beyond local and national boundaries plus has been praised by an international audience deserves special attention.

It is necessary to point out that, in general, the topics this production company approaches are about the past and the ancestral lifestyle, rather than the present and its problems, whatever the genre. In fact, there are few Isuma films that are about current topics and relate to the youth. To be more specific, there are only four documentaries that are not about traditional practices or past problems. These are Nipi, Artcirq, Qallunajaut and Kiviaq vs. Canada. Even in fictional productions, such as the TV series Nunavut or films like Atanarjuat, the main objective is to recreate traditional lifestyle and the transmission of Inuit myths.

Isuma attempts to heal the numerous injuries and wounds it has as a result of colonization, such as the expulsion of their land, sedentary life style, and Catholicism and Anglicanism that demonize their beliefs, through the recovery and reconstruction of the Inuit old way of life from the Elders' discourses, appropriating their culture and with their own voice. This is certainly a needed and effective memory therapy to cure a widespread feeling in this type of community whose recent history has been suffering from the imposition and manipulation of foreign elements. This implies, however, the risk of indirectly neglecting younger generations who have a serious identity problem. Such problem is mostly reflected in the high rate of suicide, unemployment and drug addiction among the younger members of the Inuit community.

However, it is also true that the use of audiovisual tools and new technologies is already a way to get closer to young people. This is mainly because they are a more attractive transmission media and can better relate to the new generations. These tools allow not only oral but also visual transmission, in addition to having the ability to store all this ancient wisdom to pass on to future 
generations after overcoming physical and temporal boundaries. Finally, they are a method to repair the intergenerational gap largely caused by the youth abandoning their home communities.

In conclusion, Isuma's case is remarkable as a leader for other indigenous communities in the field of reappropriating culture through the use of new technologies. It has been through this production company that the Inuits have taken audiovisual tools and adapt them to their needs and their world. However, Isuma's highest accomplishment cannot be found just in the appropriation of technologies that should have been classified as new technologies. Neither is it due only to its self-management nor to its internet platform. But its main accomplishment is the fact that it managed to narrow the generational gap transmitting knowledge through tools used by new generations. Moreover, Isuma has simultaneously gone beyond its community borders and those of the nation that hosts them, Canada. On one hand, it has been internationally appreciated and awarded. On the other hand, it has created a network of knowledge and a platform for millions of producers and indigenous communities through its platform Isuma TV.

The lack of studies, new paradigms and innovative initiatives in the field of participatory communication for social change that successfully combines new technologies with traditional media, such as the lack of interest in some appealing initiatives on indigenous communities in the North, justify the need to stop and learn from successful and exemplary experience led by communities like Inuit, Sami, Maori and other American Indian groups.

A comprehensive overview of the many strategies utilized to put the media in the service of human development should lead to the conclusion that each community should be able to choose and design the best model to meet their own needs. In order to make the best choice, it is necessary to reformulate many prejudices and accept that ICTs can be much closer to any citizen than is often thought.

\section{Bibliography}

Acevedo Ruiz, Manuel. "Información, conocimiento y tics: la cooperación al desarrollo en la sociedad red." Paper presented at Aula Solidaridad, Comillas, Universidad Pontificia de Comillas, April 20, 2006.

Acevedo Ruiz, Manuel. “Los desafíos para la integración de las TIC en una cooperación en red." Paper presented at Cooperación 2.o, I Encuentro Internacional sobre TICS para el Desarrollo. Gijón, FIDMA, January 30-31, 2008. 
Alí, Maurizio. "Medios de comunicación, asuntos étnicos e intercultura en Colombia.” Razón y Palabra 74 (2010). <http://www.razonypalabra.org.mx/N/N74/VARIA74/23 AliV74.pdf>.

Beltrán Salmón, Luis Ramiro. "Un adiós a Aristóteles: La comunicación 'horizontal." Comunicación y Sociedad 6 (1981): 5-35. <http://www.alaic.net/portal/revista/r7/ art_01.pdf>.

Beltrán Salmón, Luis Ramiro. "La comunicación para el desarrollo en Latinoamérica: un recuento de medio siglo." Paper presented at III Congreso Panamericano de la comunicación, Universidad de Buenos Aires, July 12-16, 2005.

Browne, Stephen. "Introduction: rethinking capacity development for today's challenges." In Developing Capacity through Technical Cooperation, edited by Stephen Browne, iv-vi. Virginia: Earthscan Publications, 2002.

Calvelo Ríos, Manuel. “La pedagogía masiva multimedial." Revista Latinoamericana de Estudios Educativos 4 (1998): 197-205. < http://www.redalyc.org/articulo.oa?id $=27028409 \mathrm{P}$.

Castells I Talens, Antoni. "Cine indígena y resistencia cultural." Chasqui 84 (2003): 50-57.

Cumbre Mundial sobre la Sociedad de la Información. Declaración de principios. Construir la Sociedad de la Información: un desafí global para el nuevo milenio. Documento WSIS-03/GENEVA/4-S. ONU-UIT (2004). <http://www.itu.int/wsis/ docs/geneva/official/dop-es.html>.

Del Valle, Carlos. "Mediacentrismo e invisibilización de lo étnico como objeto de estudio: una genealogía crítica de la comunicación intercultural." Signo y Pensamiento 46 (2005): 51-64. <http://revistas.javeriana.edu.co/index.php/signoypensamiento/ article/view/3665/2944>.

Dowell, Kristin. "Indigenous media gone global: strengthening indigenous identity on- and off-screen at the First Nations/First Features film showcase." American Anthropologist 2 (2006): 376-384. DOI: 10.1525/aa.2006.108.2.376.

Ginsburg, Faye. "The parallax effect: the impact of aboriginal media on ethnographic film." Visual Anthropology Review 2 (1995): 64-76. <https://files.nyu.edu/fg4/public/ pdfs/Ginsburg\%20-\%20The\%2oParallax\%2oEffect.pdf>.

Ginsburg, Faye. "Rethinking the digital age." In Global indigenous media: cultures, poetics, and politics, edited by Pamela Wilson y Michelle Stewart, 289-293. Durham: Duke University Press, 2008.

Girard, Bruce, ed. Secreto a voces. Radio, NTICs e interactividad. Roma: FAO, 2004.

Gumucio-Dagron, Alfonso, ed. Haciendo olas. Estudio de comunicación participativa para el cambio social. Nueva York: The Rockefeller Foundation, 2001.

Gumucio-Dagron, Alfonso. "El cuarto mosquetero: la comunicación para el cambio social."Investigación y Desarrollo 12 (2004a): 2-23. <http://www.redalyc.org/articulo .oa?id=26800101 $>$. 
Gumucio-Dagron, Alfonso. “¿Prometeo viajando en Cadillac?: los telecentros como el prometido fuego del conocimiento." Signo y Pensamiento 44 (2004b): 84-91. <http:// revistas.javeriana.edu.co/index.php/signoypensamiento/article/view/3656/2936>.

Gumucio-Dagron, Alfonso. "Televisión comunitaria: ni pulpo, ni púlpito, Pálpito." Infoamerica (2006). <http://www.infoamerica.org/articulos/textospropios/gumuciozb .htm>.

Lachance, Denis. "Les inuit du Québec." In Perspectives anthropologiques. Un collectif d'anthropologues québécois, edited by Louis Jaques Dorais: 289-303. Montréal: Les Éditions du Renouveau pédagogique, 1979.

Lewis, Peter, ed. Medios de comunicación alternativos: La conexión de lo mundial con lo local. París: UnESCO, 1995 .

Lorena Caballero Sybil. "Prácticas emergentes: la ciberdemocracia, las telecomunidades de conocimiento y los telecentros como alternativa para el desarrollo." Cuadernos del CENDES 58 (2005): 97-116. <http://mcendesweb.cendes.ucv.ve/ cendesphp/pdfs/revista58/58,5\%20caballero.pdf >.

Marthoz, Jean Paul. "Comunicarse en un mundo globalizado." In Globalización, crisis ambiental y educación, edited by José Ignacio Flor y María Novo Villaverde, 141-154. España: Ministerio de Educación, 2002.

Nath, Vikas. "Knowledge networking for sustainable development." KnowNet Initiative (2000). <http://216.197.119.113/vikas/exchanges-ict.html>.

Pentland, Alex (Sandy), Fletcher, Richard and Hasson, Amir. "DakNet: rethinking connectivity in developing nations." Journal Computer 37 (2004): 78-83. DOI: 10.1109/ MC.2004.1260729.

Servaes, Jean. “Comunicación para el desarrollo. Tres paradigmas, dos modelos.” Temas y Problemas de Comunicación 10 (2000): 5-28. <http://www.unrc.edu.ar/unrc/ comunicacion/dptocomunicacion/temasyproblemas/pdf/temasyproblemas_10 $. \mathrm{pdf}>$.

Servaes, Jean. "Los medios de comunicación: globalización a través de la localización." Revista Científica Digital 3 (2001). <http://www2.metodista.br/unesco/PCLA/ revista7/artigo\%207-3.htm\#Principaislinks>.

Tabing, Louie. How to do Community Radio. A primer for Community Radio Operators. Nueva Delhi: Unesco, 2004. 